\title{
Sigrid Ørevik
}

PhD candidate

Departement of Foreign Languages

University of Bergen

\section{From 'essay' to 'personal text':}

\section{The role of genre in Norwegian EFL exam papers 1996-2011}

\begin{abstract}
This article investigates developments in the use of genre in Norwegian EFL exam papers for first-year upper secondary school during the time period from 1996 to 2011. It describes genres rendered in texts for reception (attached text material) and texts for production (task options in the main exam assignment) in the two curriculum periods Reform 94 and the Knowledge Promotion of 2006. Genre-related patterns are identified and compared, and the aspect of multimodality in texts for reception and production in EFL exams is discussed. Sixteen exam papers from 1996 to 2011 comprise the corpus material of the study. Genres rendered in attached text material are categorized, as well as specified and inferred genre instructions in the chief assignment for text production. The mixed method study combines quantitative and qualitative analyses. The results show significant changes in genres rendered in texts for reception. A few computer-generated genres are observed in the last curriculum period; but no increase in multimodal texts from R94 to LK06 is observed. The range of genres for production remains largely unchanged through the period of investigation, although the distribution among the genres changes. Moreover, genre instructions in text assignments are, to a certain extent, unclear or mixed in both curriculum periods, although more so in R94 than in LK06. Based on these findings the article suggests further investigation and debate concerning genre awareness connected to EFL exams, among education authorities as well as among teachers and students of English.
\end{abstract}




\section{Introduction}

\subsection{Background}

The English language constitutes an integrated part of life for most Norwegian teenagers. For generations of Scandinavians television and cinema have been regular providers of authentic English speech, since subtitles are preferred to voice dubbing in this part of Europe. As various electronic media have developed, the impact of English has increased even further. According to the report English in Europe - 2002, for example, Norwegians in their early teens stipulated that 34\% of their English knowledge and skills originated from media (Ibsen, 2004). Furthermore, the fact that young people in the $21^{\text {st }}$ century become acquainted with a range of ICT-generated genres in the English language through web 2.0 sites etc. means that their repertoire of genres extends far beyond the traditional written genres taught in EFL (English as a Foreign Language) courses at school. Norwegian education authorities have tried to keep pace with the electronic revolution by initiating ICT-related learning projects, in-service training for teachers (see, for example, Erstad, 2004), laptops for students in upper secondary school, and electronic exams. Hence, ICT as a tool is certainly present in school settings as well as in leisure activities and work life. An interesting question is, then, how electronic media influence the range of genres used in teaching and testing. Although teaching and testing can be based on various methods and material, this article is based on the assumption that published teaching material and national exam papers can give strong indications concerning the role of genre in EFL courses. Referring to recent surveys, Ellingsund and Hellekjær (2009) argue that "textbooks and examinations exert a perhaps greater influence on teaching in Norwegian schools than do the curricula and syllabi” (p. 21). As part of a project concerning the role of genre in Norwegian EFL material for teaching and testing in upper secondary school, the present study will, therefore, investigate the range of genres rendered in exam papers, and to what extent electronically generated genres (e-mail, blog, etc.) are represented, compared to traditional, print-based genres (article, letter to the editor, etc.).

Examination assignments have also been analyzed in a large-scale project concerning quality assurance and learning output in the Norwegian L1 (first language) subject in lower secondary school. The research has been carried out by Berge, Evensen, Hertzberg and Vagle (2005), who regarded the L1 exam as a valuable source of information concerning the outcomes of learning processes. A wide range of aspects were investigated, such as assessment criteria, students' texts, external examiners' comments, etc. Especially interesting in this connection, however, is the part concerning written genres in L1 exam papers. In the years from 1998 to 2001 twelve different genres were identified, with article, essay, narrative, short story, and letter as the most central genres, while narrative and short story were the genres most frequently given. Nevertheless, 
closely following in numbers was the type of assignment simply requiring a 'text' or containing no genre instruction at all (Berge et al, 2005).

The present study will, in a similar way, attempt to establish genre patterns in texts for reception (text attachments) and texts for production (writing tasks) in first year national written EFL exams in Norwegian upper secondary school during the last two curriculum periods: Reform 94 (1994-2006) and the current Knowledge Promotion of 2006 (abbreviated R94 and LK06 respectively). In short, the research questions of this project will be:

- Which genres are rendered in text material attached to exam questions?

- Which genres are prescribed, or can be applied, in the most comprehensive assignment of the exam paper ('langsvarsoppgaven')?

- To what extent have genres in exam papers changed through the period of inquiry (1996-2011)?

- Are the same tendencies observed in genres for reception and genres assigned for production?

The article is structured as follows: the second part of the introductory section gives a short outline of EFL as a subject in the Norwegian school system. Section two contains a discussion of the role of genre in EFL teaching; the third section outlines the material and method on which the study is based; the fourth section describes the results, and the final part of the article discusses the most salient findings of the project.

\subsection{EFL in the Norwegian school system}

English is one of the core subjects in the Norwegian national curriculum, amounting to 555 teaching hours of English through ten years of compulsory education. Moreover, as most Norwegian sixteen-year-olds continue with either two vocational or three academic years of upper secondary school, they are given a further 140 hours of tuition in the English language. As most students will at this stage have acquired a fairly solid base in English, the EFL subject curriculum prescribes rather ambitious learning objectives on three levels. The first category of competence aims, 'language learning', concerns the student's own strategies and monitoring of his or her learning progress. 'Communication' constitutes the most extensive set of competence aims, listing aspects of oral and written interaction, including specifications such as "use technical and mathematical information in communication" and "produce composite [multimodal] texts using digital media" (LK06). Finally, the section 'Culture, society and literature' describes the content aspect of the subject, which comprises various literary genres and periods as well as topics related to culture in the English-speaking world.

Each year a random selection of students are drawn either for an oral exam which is locally arranged, or a nationwide written examination, where regional 
education authorities have the responsibility of ensuring an even distribution of exam subjects and number of candidates among the schools.

To simplify somewhat, the basic format of the five-hour written EFL exam is as follows: The paper consists of two main parts, the second comprising the most comprehensive assignment, which tests the student's ability to write a structured and coherent text of a certain length. The first part consists of short tasks testing skills such as comprehension (mainly R94) and knowledge about linguistic structures, levels of formality, etc. (mainly LK06), as well as communicative skills (both). Apart from the task instructions the exam paper contains text material of various kinds, which creates a point of departure for one or more of the assignments. The object of inquiry in this study will be the genres rendered in the text attachments provided with the exam papers (texts for reception) and the genres represented in the most comprehensive written assignment of the exam (texts for production).

\section{The role of genre in the first year course of English}

\subsection{Theoretical approaches}

Swales (1990) defines genre as a class of communicative events sharing a set of communicative purposes. The recognition of these communicative purposes by "expert members of the parent discourse community" constitutes the rationale of the genre, which "shapes the schematic structure of the discourse and influences and constrains choice of content and style". Consequently, "exemplars of a genre exhibit various patterns of similarity in terms of structure, style, content and intended audience" (p. 58). When working with, for example, job applications in EFL classrooms, students will most likely be instructed to use "a clear, professional layout" and write in "a polite, formal tone" (Rodgers, Sandor, \& Skifjeld, 2006, p. 196), as these are universally recognizable characteristics for this particular genre.

Although genre categorization appears to be a self-evident aspect of language and text studies, the role of genre in EFL teaching is debated from various angles. Johns (2002) mentions the disagreement about the stability of genres as one topic of discussion; whether genres can actually be sufficiently described by teachers and subsequently captured by students and thus constitute a defined part of a curriculum. Kress (1989) lists a number of assumptions shared by genre theorists, among them a conviction that "given the social provenance of genres, different genres 'have', convey and give access to different degrees and kinds of social power" (cited in Johns, 2002, p. 54). It is obvious that students who are not familiar with a given genre and its characteristics will have difficulties both interpreting and producing a text of this particular type, and thus be kept out of arenas where this genre plays a significant role. Immigrants, for instance, have in some cases been known to 
struggle in exam situations, not because they lack intellectual resources, but because they are unfamiliar with the genres represented in exam papers. These cultural obstacles to communicative and appropriate text production are, in the view of some genre theorists, quite possible to remedy. Johns (2002) refers to the Sydney school practice of a teaching/learning cycle, where teachers demonstrate features pertaining to specific genres, then help the students investigate and discuss the social purposes of each genre.

A somewhat different approach to the teaching of genres can be seen in what is currently referred to as the North American 'new rhetoric' tradition (Freedman \& Medway 1994; Devitt, 2009). This approach focuses on the fact that genres are not static; they "evolve, develop and decay" (Miller, 1984). Freedman refers to e.g. Miller (1984) and Swales (1990) as seminal theorists in the reconceptualization of genre as "social action or rhetorical responses to recurring situations or contexts" (1994, p. 194). Drawing on research carried out by e.g. Herrington (1985) and McCarthy (1987), as well as her own studies, Freedman maintains that mastery of genre depends on tacit knowledge, i.e. acquisition through exposure and practice, rather than the learning and application of prescribed rules. In her view, genre-related teaching should take the form of consciousness-raising activities, for example, through context-based studies of good text models combined with the practice of writing (Freedman, 1994).

\subsection{EFL objectives}

Since EFL exam questions are based on the learning objectives formulated in national EFL subject curriculum, it is highly relevant to observe how R94 and LK06 approach the aspect of genre. In R94, one of the competence aims is rather specific concerning genre:

The student should acquire good skills in written communication, suited to the purpose of the writing and to the addressee. The student should (...) be capable of writing various types of text, such as story; formal letter; application; report; [texts showing] coherent reasoning. (Objective 4, The Use of Written English; my translation).

The Education Ministry's assessment guidelines for the 1999 exam (The National Exam Committee, 1999, preliminary edition) display, however, a more careful approach to the mastery of genre as a criterion for assessment. A good text should be communicative, coherent, and pay attention to the purpose of the communication (context, addressee, etc.). Admittedly, the guidelines recommend a language usage which is "(...) idiomatic in relation to genre. Ellipses may, for instance, have a disturbing effect in a discussion, whereas they can function as effective literary devices in a story or a description" (1999, p. 17; my translation). It seems, nevertheless, that the National Exam Committee would not like to see too rigid genre requirements spoil a favourable assessment 
of students' texts that are otherwise well structured, idiomatic in language, and display independent and mature reflection.

Although the LK06 EFL subject curriculum recognizes that "[c]ommunication (...) includes participation on various social arenas, where it is important to train to master an increasing number of genres and forms of expression", the competence aims seem to relate to genre indirectly: "The aims are that the pupil shall be able to (...) express himself/herself in writing and orally with subtleness, proper register, fluency, precision and coherence” (Norwegian Ministry of Education, 2006). It is only the objective concerning communication strategies that specifically mentions genre awareness, in requiring that students "select appropriate (...) writing strategies adapted to the purpose, situation and genre". Furthermore, the subject curriculum prescribes the writing of texts on several levels of formality, about personal, social/political, and interdisciplinary themes; in other words, structure, focus, and coherence are apparently more important parameters in assessing the student's writing competence than the knowledge and mastery of genre.

\section{Material and method}

\subsection{Selection of material}

The corpus material for the present study consists of 16 EFL examination assignments from R94 and LK06, eight from each period. In order to be as representative as possible, the selection of exam papers covers early years as well as middle and later years of the two curriculum periods. Spring exam papers dominate, since a vast majority of students sit for exams in May.

\subsubsection{Genres for reception}

Each exam paper contains one or more pages of text previously unknown to the student, which "sets the scene" for the topical theme of the exam paper and may serve as point of departure for the testing of various linguistic skills. Two aspects of the LK06 exam format extend, potentially, the range and volume of texts for reception. Firstly, the students are now permitted to bring with them an unlimited amount of books, notes, printed pages, references, etc. for the exam, which are outside the scope of the present analysis. Secondly, official preparation material is now handed out to the students on a preparatory day prior to the exam. All texts for reception pertaining to each set of exam assignments and to the official preparation documents, with the exception of instructions and assessment criteria, will be registered in genre categories according to criteria connected to communicative purpose (see Swales 1990) and channel or medium through which they conventionally occur. Citing the initial part of Bhatia's (1993) procedure for genre analysis, the text is "[placed] intuitively in a situational context by looking at one's prior experience, the internal clues in the 
text and the encyclopaedic knowledge of the world that one already has” (p. 22). For instance, short texts making frequent use of the second person singular pronoun, calling for applications and providing contact information, are recognized as a type of 'advertisement' conventionally appearing in newspapers and magazines. The following genres are identified and will function as categories of texts for reception in the present study:

- Formal letter

- Letter to the editor

- Advertisement

- Article

- Newspaper report

- Informative text (instructions or information on a particular topic)

- Literary prose (e.g. short story or excerpt from novel)

- Poem or song lyrics

- Constructed dialogue or citation (composed exclusively for the exam paper)

- Comic strip

- Blog

- Specialized website (website concerning particular interests or topics)

\subsubsection{Genres for text production}

The main task in each exam paper requires that the candidate write a text of a certain length, choosing from three to five alternative assignments. In some cases, the genre is specified; in others, genre is not mentioned and instructions involving genre characteristics may point in several directions. In those cases, genres that might suit the assignment will be suggested on the basis of interpreted communicative purposes (cf. 3.2.1). More than one alternative may be presented as genre identification in tasks that can be construed as open to several angles of interpretation. The following genres are identified and will function as specified and interpreted categories of texts for production:

- Article

- Feature article

- Essay

- Letter to the editor

- Informative text (instructions or information on a particular topic)

- Promotional text (e.g. text promoting a place or an institution)

- Story (short story or other types of literary prose)

- Diary entry

- Presentation (written or transcribed oral text about a topic presumed unknown to the audience)

- Manuscript for a talk 
In addition, there are certain categories which cannot immediately be placed in a genre according to convention and communicative purposes, namely 'text' and 'personal text' as specific genre instructions, and exam questions where genre instructions are construed as, respectively, 'mixed' and 'unspecified'. In these cases, task instructions will be interpreted in terms of potentially suitable genres (see above).

'Traditional genres' will, in the present study, label written, print-based ('pre-digital') genres which are well-established in Norwegian EFL classrooms as well as in authentic discourse outside school. Examples are article, newspaper report, short story, etc. The concept 'digitized genres', on the other hand, will denote genres generated by digital media, such as e-mail and blog. Even if some electronic text categories are known to be extremely 'elastic' and varied, they will be treated as genres in this connection. As Myers (2010) puts it: "Blogs and wikis are genres of texts defined not so much by their form or content as by the kinds of uses to which they are put (...)” (Myers, 2010, p. 15).

Certain text types seem to be formed and have their sole purpose within school contexts, and can, therefore, be grouped in a 'school genre' category. Bazerman refers to analytic essay as a school genre, as opposed to 'disciplinary, professional and community genres' (2007, p. 5). In pre-R94 exam assignments 'essay' functioned as a versatile genre instruction, as explained in Simensen (1998): "The term 'essay' in a school context is used as a common denominator for various types of coherent writing such as writing letters, descriptions, narratives, expositions etc” (p. 202). Norwegian R94 assessment guidelines, however, lean more towards the traditional understanding of the concept in stating that 'essay' is a suitable genre "when the candidate is asked to reflect on a question to clarify questions for himself/herself" (National Exam Committee, 1999, p. 15, my translation).

'School genre' can also be applied to a type of text for production found in the present research material where the student is invited to display knowledge about syllabus-related topics while drawing on his/her personal experience or opinion:

During your foundation English course you have read at least two short stories or excerpts of a play and a novel.

Pick a character in two of these texts. Describe these two characters and the situation they are in. Then explain why you chose these two in particular. (Spring 1996, task c)

This brings us to the concept 'personal text', which is used in assignments from both curriculum periods. From examples found in the present corpus it seems to function as a 'hold-all' genre, especially in tasks involving literary texts. In this way the constraints of traditional genres such as literary analysis or book review can be avoided (e.g. task 3c in spring 2007, see section 4.2.2). Hellekjær (2008) refers to discussions around this particular genre in the assessment process of the 
spring 2007 exam, where the conclusion was "to accept different varieties as long as the language was suitable for a school magazine” (p. 60); i.e., the medium and the target group are specified, but the genre is vague. In discussions of interpreted genre instructions, this article will define 'personal text' as a genre for production where the assignment calls for the candidate's personal situation or experiences, i.e. follow the use of the concept observed in the following example: "To what extent is English relevant for your area of study and future profession? (...) Write a personal text in which you reflect upon this question" (Spring 2002, task d).

\subsection{Quantitative and qualitative analyses: Mixed method}

Since several aspects of the genre angle are relevant in the present study, a combination of quantitative and qualitative methods will be employed, i.e. a 'mixed method' as described by Dörnyei (2007): “A mixed methods study involves the mixing of quantitative and qualitative data in a single study with some attempts to integrate the two approaches at one or more stages of the research process" (p. 163).

Thus, comparisons concerning genre categories and distribution will be made between texts for reception in R94 and LK06 (see figure 4.2.a below), as well as between texts for production in the two curriculum periods. All optional texts for production in the main exam assignment will be presented in tables where explicit genre instructions (or zero genre instructions) will be compared to inferred genre(s), based on interpretation of the assignment (figures 4.1.b and 4.2.b). Change and development concerning genre patterns will, subsequently, be analyzed and discussed. The range of genres for reception and production in Norwegian EFL exams will then be compared, with a special view on ICTgenerated genres and the aspect of multimodality. The concept 'multimodal' is in the present study applied to texts composed by means of several semiotic resources (see Skulstad, 2009), e.g. texts where written words are combined with visuals (images, etc.) and/or insertions via electronic devices (sound files, hypertext, etc.). 


\section{Results}

\subsection{Reform 94}

\subsubsection{Texts for reception}

Altogether 26 texts for reception appear in the R94 material, of which the dominating genres are traditional and print-based; for example, advertisement, formal letter and literary prose. Eight texts can be categorized as multimodal, consisting of printed text and illustrations in various forms; these are also predominantly 'analogue'. There is one exception, however; in the 2003 exam the main text attachment pertains to an electronic genre: a website about fantasy literature. It should also be noted that a short story (2005) and a letter to the editor (2005) are both taken from the Internet, continuing a careful move towards electronic media as a provider of text material.

\subsubsection{Texts for production}

In the R94 sets of assignments, the introduction to the main task instructs the candidates to choose among a list of topics. No length of the text is indicated, explained by the principle that length is no definite criterion of quality, as long as there is enough text material at hand to give proper assessment in the light of the task and the communicative situation (Gulbrandsen, 1997).

As far as traditional genres are concerned, story is the most frequent specified genre, comprising a quarter of the task options. A few assignments give specifications such as fantasy story (1998) and science fiction story (2003), or the student is asked to compose a fictional text using an authentic literary text as point of departure $(2001 ; 2005)$. Article comes in second among specified genres, given six times in R94 exam papers (1996; 1999; 2002; 2003; 2005). Among the exam sets in the R94 corpus, spring 1999 is most consistent in presenting clear genre instructions for the main assignment. Here the students are asked to select one or two pictures from a collection of twelve images illustrating aspects of the UK, and to write within one of the genres article, story or, alternatively, an informational or promotional text for a brochure. The enclosed information about assessment instructs the student to "consider the target group of the text, and employ linguistic effects typical of the chosen genre" (my translation).

All other R94 sets included in my material, however, contain assignments where genres are suggested indirectly. 12 out of 35 options for the main task (34 percent, or one-third) either require a 'text' or give no genre specifications at all. In these cases, interpreted genres are suggested, of which article is the most frequent (1998; 2000; 2005). 
Figure 4.1.b below presents interpreted as well as specified genre instructions in R94 assignments, 'S96-a' meaning the first task among the options in the spring 1996 material, and so forth.

\begin{tabular}{|c|c|c|c|c|c|c|c|c|}
\hline & Specified & Interpret. & & Specified & Interpret. & & Specified & Interpret. \\
\hline S96-a & Article & $\begin{array}{l}\text { Feature } \\
\text { article }\end{array}$ & S98-a & Text & $\begin{array}{l}\text { Feature } \\
\text { article }\end{array}$ & S-99a & Article & Article \\
\hline S96-b & Unspecif. & $\begin{array}{l}\text { Essay or } \\
\text { letter to the } \\
\text { editor }\end{array}$ & S98-b & Unspecif. & Article & S99-b & Story & Story \\
\hline S96-c & Unspecif. & Mixed & S98-C & $\begin{array}{l}\text { Presen- } \\
\text { tation }\end{array}$ & $\begin{array}{l}\text { Manuscr. } \\
\text { for a talk }\end{array}$ & S99-c & $\begin{array}{l}\text { Inform. } \\
\text { text }\end{array}$ & Inform. text \\
\hline S96-d & Unspecif. & $\begin{array}{l}\text { Personal } \\
\text { text }\end{array}$ & S98-d & Unspecif. & Mixed & S99-d & $\begin{array}{l}\text { Promo- } \\
\text { tional text }\end{array}$ & $\begin{array}{l}\text { Promo- } \\
\text { tional text }\end{array}$ \\
\hline S96-e & Story & Story & S98-e & Story & Story & & & \\
\hline & Specified & Interpret. & & Specified & Interpret. & & Specified & Interpret. \\
\hline s00-a & Text & Article & S01-a & Text & $\begin{array}{l}\text { Inform. } \\
\text { Text }\end{array}$ & SO2-a & $\begin{array}{l}\text { Personal } \\
\text { essay }\end{array}$ & Essay \\
\hline s00-b & $\begin{array}{l}\text { Story or } \\
\text { diary }\end{array}$ & $\begin{array}{l}\text { Story or } \\
\text { diary }\end{array}$ & S01-b & Story & Story & SO2-b & Article & Article \\
\hline SO0-c & $\begin{array}{l}\text { Presen- } \\
\text { tation }\end{array}$ & $\begin{array}{l}\text { Feature } \\
\text { article }\end{array}$ & S01-C & Essay & Essay & SO2-C & Story & Story \\
\hline s00-d & Text & Mixed & S01-d & $\begin{array}{l}\text { Personal } \\
\text { text }\end{array}$ & Essay & SO2-d & $\begin{array}{l}\text { Personal } \\
\text { text }\end{array}$ & $\begin{array}{l}\text { Personal } \\
\text { text }\end{array}$ \\
\hline & Specified & Interpret. & & Specified & Interpret. & & & \\
\hline S03-a & Article & Article & S05-a & Text & $\begin{array}{l}\text { Article or } \\
\text { letter to the } \\
\text { editor }\end{array}$ & & & \\
\hline S03-b & Text & $\begin{array}{l}\text { Letter to } \\
\text { the editor }\end{array}$ & S05-b & Article & $\begin{array}{l}\text { Article or } \\
\text { essay }\end{array}$ & & & \\
\hline S03-c & $\begin{array}{l}\text { Personal } \\
\text { text }\end{array}$ & Mixed & SO5-c & Text & $\begin{array}{l}\text { Personal } \\
\text { text }\end{array}$ & & & \\
\hline S03-d & Story & Story & S05-d & Story & Story & & & \\
\hline S03-e & Article & Article & & & & & & \\
\hline
\end{tabular}

Fig. 4.1.b: Specified and interpreted genres for production in R94

Several examples of mixed genre instructions can be observed in the R94 material. The fourth alternative in the spring 2003 exam, for example, specifies fantasy story as genre, but instructs the candidate to use his or her knowledge about the USA or the UK to create a convincing setting. In most other types of story this backdrop would, of course, function adequately, but fantasy literature normally operates with fantasy settings. A typical example of a 'school genre' as described in section 3.2.2 is found in the spring 2000 exam, where one of the tasks requires a text for a camp newspaper about new trends and changes in the candidate's area of study, and which skills might be needed in his or her future profession. The last sentence in the assignment addresses the candidate personally: "Are you trained for this future?" Thus, the beginning of the assignment text indicates an article or feature article, while the ending points more in the direction of a personal text. 


\subsection{LK06: "Kunnskapsløftet” (The National Curriculum for Knowledge Promotion)'}

\subsubsection{Texts for reception}

The 39 texts for reception in the LK06 material is a higher figure than in the R94 papers, which is probably due to the introduction of preparation sheets in addition to the texts included in the exam paper.

Early exam papers in LK06 give signals of a certain degree of multimodality making its way into the exam genres. In the spring 2007 preparation sheet, for example, illustrations depicting books and films, with small captions inserted, are incorporated in the text which gives the candidates instructions on what to prepare for the exam. A similar collage-type mixture of texts and pictures is found in the preparation material for the exam given in November, 2007. Here the texts themselves represent a broad range of genres, including a traditional poem, a prose-poem, a historical timeline, and (constructed) comments from the street. The preparation sheet provides, in addition, a list of Internet links, inviting the student to consult and print web sites relevant to the theme of the exam. An example of the influence exerted on text genres by electronic media can also be detected in the May, 2007 exam paper, where a copy of a blog is provided as text attachment. In this case, the printed text, describing a Mediterranean holiday resort, is surrounded on two sides by illustrating photos forming vertical columns, which are, presumably, "clickable" in the original, digital text. Recent exam papers, on the other hand, show very few traces of multimodality. Some of the informative texts of reception are digitized in the sense that they are based on specialized websites (2008; 2011), and are therefore categorized as 'website' rather than 'informative text'. These texts are, nevertheless, paragraphed texts fairly traditional in their layout.

The category of texts for reception with the highest frequency in LK06 is what EFL didactics would label 'constructed' texts (Widdowson, 1998; Fenner, 2006), i.e. texts composed exclusively for school purposes, with Utdanningsdirektoratet (the Norwegian Directorate for Education and Training) given as source reference. These are generally written in the form of a dialogue or a citation. The autumn 2009 exam, for example, contains a text entitled "A Year in Hong Kong”, which is a composed text resembling an extract from a talk or an interview. 
Fig. 4.2.a below shows the distribution of the most frequent genres for reception in the two curriculum periods: formal letter, letter to the editor, advertisement, literary prose, newspaper report, specialized website, song lyrics/poem, and constructed dialogue/citation.

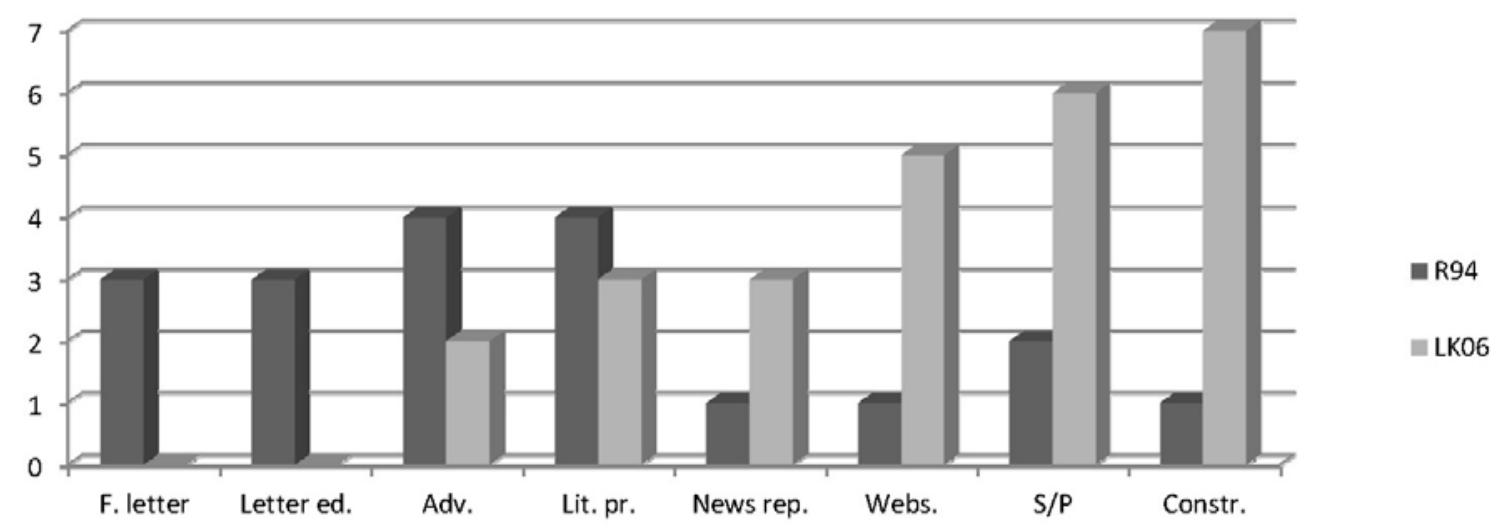

Fig. 4.2.a: Most frequent genres for reception in R94 and LK06 exam assignments

As we see, there is a shift in distribution of genres for reception from R94 to LK06. Whereas advertisement and literary prose are frequent genres in R94, they are surpassed by the categories specialized website, constructed dialogue/citation and song lyrics/poem in LK06. Moreover, the formal letter and letter to the editor as texts for reception are not seen in the LK06 part of the corpus.

\subsubsection{Texts for production}

As far as literary genres are concerned, short story and biography are specified as genre in a few LK06 assignments, representing a more precise genre instruction than the wider concept 'story' in their R94 counterparts. Although essay is given as genre instruction only once in the present corpus, there are five tasks where the essay genre (as described in the citation from the National Exam Committee 1999 in section 3.2.2) could be applied. Article is, however, by far the most frequent traditional genre for production in the present curriculum period, constituting 32 percent of the specified genre instructions (2007; 2008; 2010; 2011). In most cases, though not all, a context for the article is given, e.g. a magazine for young people.

One 2010 task specifying article as genre is, however, less than clear-cut in its genre instructions. The headline is as follows: "Life isn't always fair, but you have to do the best with what you've got”. Literary characters and/or real-life figures are to be included for reference. It seems that this assignment may call for a mixing of genres, in that elements of biography and essay could easily find 
their way into the text. A certain inconsistency is also seen in an autumn 2011 assignment, which requires an article for young people about the dangers of using the Internet, but where a bullet point directs the candidate to end his or her text with "a conclusion with your overall view of young people using the Internet” (A2011-d).

\begin{tabular}{|c|c|c|c|c|c|c|c|c|}
\hline & Specified & Interpret. & & Specified & Interpret. & & Specified & Interpret. \\
\hline $\begin{array}{l}\text { S07- } \\
\text { a }\end{array}$ & $\begin{array}{l}\text { Manuscript } \\
\text { for a talk }\end{array}$ & $\begin{array}{l}\text { Manuscript } \\
\text { for a talk }\end{array}$ & $\begin{array}{l}\text { A07- } \\
\text { a }\end{array}$ & Article & Article & $\begin{array}{l}\text { S08- } \\
\text { a }\end{array}$ & Text & $\begin{array}{l}\text { Article or } \\
\text { feature } \\
\text { article }\end{array}$ \\
\hline $\begin{array}{l}\text { S07- } \\
\text { b }\end{array}$ & Text & $\begin{array}{l}\text { Feature } \\
\text { article }\end{array}$ & $\begin{array}{l}\text { A07- } \\
\text { b }\end{array}$ & $\begin{array}{l}\text { Personal } \\
\text { text }\end{array}$ & Essay & $\begin{array}{l}\text { S08- } \\
\text { b }\end{array}$ & Analysis & Mixed \\
\hline \multirow[t]{3}{*}{$\begin{array}{l}\text { S07- } \\
\text { c }\end{array}$} & Personal text & $\begin{array}{l}\text { Essay or } \\
\text { feature art. }\end{array}$ & $\begin{array}{l}\text { A07- } \\
\text { C }\end{array}$ & Biography & Biography & $\begin{array}{l}\text { S08- } \\
\mathrm{C}\end{array}$ & Article & Article \\
\hline & & & & & & $\begin{array}{l}\text { S08- } \\
\text { d }\end{array}$ & Article & Article \\
\hline & Specified & Interpret. & & Specified & Interpret. & & Specified & Interpret. \\
\hline $\begin{array}{l}\text { S09- } \\
\text { a }\end{array}$ & Text & $\begin{array}{l}\text { Essay or } \\
\text { article }\end{array}$ & $\begin{array}{l}\text { S10- } \\
\text { a }\end{array}$ & Text & Essay & $\begin{array}{l}\text { A10- } \\
\text { a }\end{array}$ & Text & Article \\
\hline $\begin{array}{l}\text { S09- } \\
\text { b }\end{array}$ & $\begin{array}{l}\text { Feature } \\
\text { article }\end{array}$ & $\begin{array}{l}\text { Feature } \\
\text { article }\end{array}$ & $\begin{array}{l}\text { S10- } \\
\text { b }\end{array}$ & Article & Article & $\begin{array}{l}\text { A10- } \\
\text { b }\end{array}$ & Article & Essay \\
\hline \multirow[t]{3}{*}{$\begin{array}{l}\text { S09- } \\
\text { C }\end{array}$} & $\begin{array}{l}\text { Manuscript } \\
\text { for a talk }\end{array}$ & $\begin{array}{l}\text { Manuscript } \\
\text { for a talk }\end{array}$ & $\begin{array}{l}\text { S10- } \\
\text { C }\end{array}$ & Article & Article & $\begin{array}{l}\text { A10- } \\
\text { C }\end{array}$ & Short story & Short story \\
\hline & & & & & & $\begin{array}{l}\text { A10- } \\
\text { d }\end{array}$ & Article & Article \\
\hline & Specified & Interpret. & & Specified & Interpret. & & & \\
\hline $\begin{array}{l}\text { S11- } \\
\text { a }\end{array}$ & $\begin{array}{l}\text { Manuscript } \\
\text { for a talk }\end{array}$ & $\begin{array}{l}\text { Manuscript } \\
\text { for a talk }\end{array}$ & $\begin{array}{l}\text { A11- } \\
\text { a }\end{array}$ & $\begin{array}{l}\text { Informative } \\
\text { text }\end{array}$ & Mixed & & & \\
\hline $\begin{array}{l}\text { S11- } \\
\text { b }\end{array}$ & Text & $\begin{array}{l}\text { Essay or } \\
\text { article }\end{array}$ & $\begin{array}{l}\text { A11- } \\
\text { b }\end{array}$ & Short story & Short story & & & \\
\hline $\begin{array}{l}\text { S11- } \\
\text { C }\end{array}$ & Article & Article & $\begin{array}{l}\text { A11- } \\
\text { C }\end{array}$ & Article & Mixed & & & \\
\hline $\begin{array}{l}\text { S11- } \\
\text { d }\end{array}$ & Biography & Biography & $\begin{array}{l}\text { A11- } \\
\text { d }\end{array}$ & Unspecified & $\begin{array}{l}\text { Personal } \\
\text { text }\end{array}$ & & & \\
\hline
\end{tabular}

Fig. 4.2.b: Specified and interpreted genres for production in LK06

'Personal text' appears as a versatile but vague genre in LK06 exams (see 2.2). For example, spring 2007-c introduces the task using an informal and appealing tone: "(...) Deciding what do you do [sic] if a friend of yours does something dishonest, or if you see somebody being bullied or treated unfairly (...)?” and subsequently moves away from the personal note, requiring two literary texts as reference where characters are faced with difficulties and dilemmas.

One of the assignments in the spring 2008 exam set specifies 'analysis' as genre and requires the presentation of one or two literary texts and/or films. It is, however, exclusively the content of the literary texts or films that is focused, namely a disagreement on a political or social issue among the characters. The student is also invited to present his or her own views on the issue. In other words, the task appears to combine elements of literary analysis (plot, theme, 
possibly characterization) with a discussion of a particular topic using the literary text(s) or film(s) as background.

Seven out of 28 tasks (25\%) do not specify a genre for production; that is to say, the percentage of task options with merely 'text' as genre instruction has declined compared to the R94 material, where one-third of the assignments do not specify genre.

\section{Discussion of findings}

\subsection{Texts for reception}

While the range of traditional genres is broad in the R94 text material (newspaper article; biography; short story; formal letter; letter to the editor), the LK06 text attachments show a somewhat different pattern. Formal letters and letters to the editor, for instance, have disappeared; and the number of constructed dialogues and citations has increased. Texts adapted from websites are marginally represented in R94 exams, but are more strongly present in the selection of attached material in LK06. A closer look at the multimodal texts reveals that while one out of eight found in the R94 material is ICT-generated (a specialized website), only one out of nine multimodal texts in the LK06 sets belongs to a digitized genre (blog). Interestingly, while the early LK06 exams show considerable variation in text material, this tendency is reversed after 2008, possibly due to practical concerns such as copyright issues. Preparation material has, broadly speaking, changed from collages of authentic texts and images into constructed texts combined with bullet points providing information and key words about the main topic of the exam.

Given the frequent revisions and reforms in the EFL subject curricula, one would expect the genre patterns in the exam assignments to reflect the changes in genres used in everyday written discourse. The most significant change in the $21^{\text {st }}$ century is, of course, that the majority of an average student's daily texts for reception consist of digitized, multimodal text material. Skulstad (2009) points to the multimodal view of language now emerging among scholars; communicative situations are frequently mediated by modern technologies bringing on changes in the composition of texts, modifying established genres and generating new, multisemiotic genres.

Taking a multimodal view of language means to acknowledge the fact that multiple semiotic resources (written words, sound-tracks, visuals, video-clips etc.) combine and interact to make meaning. (p. 3)

Lund (2007) points to new, electronically generated genres emerging with their own conventions and registers, and argues that "[m]ultimodality and hyperstructures require new types of textual competence” (p. 32). If the careful 
move towards computer-generated genres that we saw in exam sets from 2006 to 2008 can be construed as an attempt to mirror the overall increase in ICT-based genres, it is somewhat puzzling to observe the new turn away from digitized genres in later exam papers. Although several texts for reception in the 2011 sets are adapted from websites, they do not follow up the signs of multimodality that were traced in early LK06 exams.

\subsection{Texts for production}

\subsubsection{The dominance of traditional text genres}

As we have seen, the traditional genres story and article dominate the texts for production in both curriculum periods, but the distribution between them changes. Story, which represents 25 percent of specific genre instructions in R94, is given in only four LK06 assignments (14 percent). Article, the other dominant genre in the corpus of texts for production, increases its proportion of genre instructions from 17 percent of the R94 task options to 32 percent in LK06.

Although written exams have been digitized in Norway for the last few years, the main assignment in EFL exams does not seem to keep pace with overall genre developments in the $21^{\text {st }}$ century. The study of Norwegian L1 exams in lower secondary schools mentioned above (Berge et al., 2005) also noted this paradox:

In a digital era where almost all text production outside school is carried out by means of computers, and where the concept of text has for years been extended to comprise multimodal expressions (writing, image, sound, diagrams, layout...) it is remarkable that writing for exams is still done within the formats and traditions of handwriting and printing press, and with a repertoire of expression dominated by linear writing. (p. 168 , my translation)

Returning to the EFL exams, there is, for example, no written text assignment in the EFL exams that gives blog as genre instruction, even though a blog does occur as text attachment in a LK06 exam set. Kress and van Leeuwen (2006) criticize the considerable discrepancy in material provided for students' consumption, with ample use of images, and material that students are required to produce for assessment, where writing still dominates. This marginalization of images in genres for production works against students' need for 'visual literacy' (p. 17). Skulstad goes in the same direction in pointing to an increasing call for multiple literacies in language learning, meaning a range of skills and competencies needed to participate and navigate in the cultural and social spheres created by new systems of communication (Kellner, 2002 and Buckingham, 2006, cited in Skulstad, 2009). Such production of computergenerated, multimodal texts is recognized by the LK06 curriculum (see above) and frequently carried out in Norwegian EFL classrooms. Evidently, the creation 
of multimodal texts in English lessons is facilitated by access to the Internet, which is not at present available to exam candidates. The Norwegian Directorate for Education and Training has, however, initiated a project involving 15 schools where candidates have Internet access during the exams in the subjects International English, Tourism, and Foreign Language II (Norwegian Directorate for Education and Training, 2012). Although this research project is yet to be evaluated (the report is due by the end of 2012), it outlines scenarios within the ICT-based exam format which could widen the range of genres that students could exploit in their text production.

Admittedly, from a language teacher's point of view it could be argued that multimodal genres are typically fragmented and therefore do not serve as optimal models for structured, cohesive writing. Even so, it need not be one or the other; tasks involving multimodal elements could be combined with the creation of linear, cohesive texts developing formal and academic writing skills. It could, for example, be possible to supplement an article with a video clip of an interview or links to relevant hypertext, as is now typical of online newspaper articles. Besides, admitting multimodality into the arena of written exams does not mean that all texts must be multimodal. The objective stated in the LK06 syllabus to "master an increasing number of genres and forms of expression" suggests that new and emerging genres as well as traditional genres should be integrated in EFL teaching, and, consequently, could be relevant parts of the repertoire of genres represented in exam assignments.

\subsubsection{Vague and mixed genre instructions}

The numerous aspects that have to be considered in the composition of exam tasks represent dilemmas that are not new: "In the academic context, a genre with high potential for conflicting purposes is that of the student written examination” (Searle, 1969; Horowitz, 1986, in Swales, 1990, p. 47). Judging from the proportion of assignments with unspecified or mixed genre instructions in the present corpus of exam papers (although this proportion has decreased from R94 to LK06, cf. 4.2.2) it seems that other principles or objectives have taken priority over genre awareness in the composition of the tasks.

Martin (1985) sees genre as an abstract representation of "the verbal strategies used to accomplish social purposes of many kinds" (p. 251, cited in Skulstad, 2002). The combination of genre characteristics associated with, for example, literary analysis and personal text in the same assignment will not, in my view, call for verbal strategies useful in future written discourse. As a school genre, however, a task with mixed genre instructions may in some cases elicit more English text production than one requiring a traditional genre. The R94 guidelines for assessment underline the necessity of "open" exam tasks, the intention being to give the students the best possible opportunity to show their knowledge (The National Exam Committee, 1999). Kjell Gulbrandsen, member of the National Exam Committee during the first decade of the R94 curriculum, 
observed that “(...) [e]vidently the candidates show more joy in writing now than we have observed earlier. It seems that we have managed to give them the opportunity to show their potential; and instructing external examiners to assess other aspects of the text than its purely linguistic qualities may also have contributed in that respect" (Gulbrandsen, 1997, my translation). This pragmatic principle is, to some extent, reflected in the LK06 objective of enabling the student to "write formal and informal texts with good writing structure and coherence based on themes that interest him/her and which are important for society" (LK06 EFL). Freedman (1994) also counts the importance of 'intention' as a prerequisite for good writing - "having something to say" (p. 201). In the case of LK06, Hellekjær points to the challenge of composing assignments for a national test on the basis of wide competence aims, for example: "The pupil shall be able to discuss social and cultural conditions and values in a number of English-speaking countries". An important purpose of the preparatory day and the preparatory material is, therefore, to narrow down the relevant topics to prepare for the main task of the exam (Hellekjær, 2008).

Returning to the findings concerning unclear genre instructions, the preparatory material could, potentially, be assigned an additional function as a source of reference. For example, the genres occurring in the texts for production could be mentioned here, with key words listing important genre characteristics. In the next run, this would, most likely, create a washback effect; i.e., to some degree influence the teaching in the relevant EFL course as far as focus on genre is concerned (see Ellingsund \& Hellekjær, 2009 for an outline of recent washback research within EFL).

\section{Conclusion}

The present study of texts for reception and production in Norwegian EFL exam papers for the first year of upper secondary school shows a pronounced difference in the genre-related development of attached text material and the genres assigned for production. While the range of genres for reception has changed significantly from R94 to LK06, the genres for production have not changed to any great extent. The proportional representation of the genres for production, however, has shifted; whereas story is the most frequent genre in R94, article holds the leading position in LK06 assignments. Digitized genres are to a certain degree represented in LK06 text attachments, unlike the main written assignment in the exam, which remains dominated by print-based genres. Another significant finding from my corpus of exam papers is that a number of task options for production give vague or mixed genre instructions, calling for text types that are mixed in a manner which does not reflect changed or hybrid genres in discourse outside school. Although the intention may be to elicit a maximum of meaningful language production, such genre instructions 
will have limited effect in developing students' genre awareness and text competence.

This article calls for a clearer genre aspect in the exam papers, expressed, for instance, through the official preparation material. It also argues that multimodality, which gains more and more territory in 'real life' discourse, should make its way into exam questions.

A challenge for Norwegian examination committees, then, will be to balance the student's need for awareness concerning genres used in professional, civic and private settings against contexts in which the student can use his or her linguistic knowledge and creativity to the full. Therefore, Norwegian school authorities, linguists and EFL teachers need to discuss what role genre awareness and the selection and teaching of genres should play in EFL subject curricula, classroom activities and exam papers, taking factors such as students' familiarity with multimodal genres into account.

\section{References}

Bazerman, C. (2007). Genre and Cognitive Development: Beyond Writing to Learn. Paper presented at SIGET: 4th International Symposium on Genre Studies, Brazil Retrieved from http://www3.unisul.br/paginas/ensino/pos/linguagem/siget/index.htm

Berge, K.L., Evensen, L.S., Hertzberg, F. \& Vagle, W. (2005). Ungdommers skrivekompetanse. Vol. 1. Oslo: Universitetsforlaget.

Bhatia, V. (1993). Analysing Genre: Language Use in Professional Settings. Harlow: Pearson Education Ltd.

Buckingham, D. (2006). Defining digital literacy. Digital kompetanse [Nordic Journal of Digital Literacy] (4), 263-276. Retrieved from www.idunn.no/ts/dk

Devitt, A. (2009). Teaching Critical Genre Awareness. In Bazerman, C., Bonini, A., \& Figueiredo, D. Genre in a Changing World: Perspectives on Writing pp. 337-351. Fort Collins, Colorado: The WAC Clearinghouse and Parlor Press. Retrieved from wac.colostate.edu/books/genre/chapter17.pdf

Dörnyei, Z. (2007). Research Methods in Applied Linguistics. Oxford: Oxford University Press.

Ellingsund, A. \& Hellekjær, G. (2009). Defining washback: An overview of the field. Språk og Språkundervisning (2), 20-28.

Erstad, O. (2004). Piloter for skoleutvikling. Samlerapport fra forskningen 2000-2004. Oslo: ITU/UiO.

Erstad, O. (2005). Digital kompetanse i skolen. Oslo: Universitetsforlaget.

Fenner, A. B. (2006). Intercultural awareness as an integral part of foreign language learning. In Fenner, A. B. \& Newby, D. (Eds.), Coherence of principles, cohesion of competences: Exploring theories and designing materials for teacher education (pp. 40-58). Graz/Strasbourg: Council of Europe.

Freedman, A. (1994). 'Do As I Say': The Relationship between Teaching and Learning New Genres. In Freedman, A. \& Medway, P. (Eds.), Genre and the New Rhetoric (pp. 191210). London: Taylor and Francis.

Freedman, A. \& Medway, P. (1994). Locating Genre Studies: Antecedents and Prospects. In Freedman, A. \& Medway, P. (Eds.), Genre and the New Rhetoric (pp. 1-20). London: Taylor and Francis.

Gulbrandsen, K. (1997). Språkfag i Reform 94, noen erfaringer. Språk og Språkundervisning (1), 24-26. 
Hellekjær, G. (2008). Ny engelskeksamen med alle hjelpemidler: Nye krav eller ny nivåsenkning? Bedre Skole (3), 56-61.

Herrington, A. (1985). Writing in Academic Settings: A Study of the Contexts for Writing in Two College Chemical Engineering Courses. Research in the Teaching of English, 19 (4), 331-61.

Horowitz, Daniel M. (1986). What professors actually require: academic tasks for the ESL classroom. TESOL Quarterly, 20 (3), 445-62. Retrieved from http://www.jstor.org/stable/3586294

Ibsen, E. (2004). Engelsk i Europa - 2002. Oslo: ILS, Universitetet i Oslo. Retrieved from www.duo.uio.no

Johns, A.M. (Ed.). (2002). Genre in the Classroom: Multiple Perspectives. London and Mahwah, New Jersey: Lawrence Erlbaum Associates.

Kellner, D. (2002). Technological Revolution, Multiple Literacies, and the Restructuring of Education. In Snyder, I. (Ed.), Silicon literacies. Communication, innovation and education in the electronic age (pp. 154-169). London: Routledge.

Kress, G. (1989). Linguistic Processes in Sociocultural Practice. Oxford: Oxford University Press.

Kress, G. \& van Leeuwen, T. (2006). Reading Images: The Grammar of Visual Design. $\left(2^{\text {nd }}\right.$ ed $)$. London/New York: Routledge.

LK06: The EFL subject curriculum, mandatory course in upper secondary school, in The Norwegian National Curriculum for Knowledge Promotion in Primary and Secondary Education and Training, 'Kunnskapsløftet'. Retrieved from http://www.udir.no/kl06/ENG1-02

Lund, A. (2007). ICT and EFL: What can we now do with language? Språk og Språkundervisning (2), 30-36.

Martin, J. R. (1985). Process and text: two aspects of human semiosis. In: Benson and Greaves (Eds), Systemic perspectives on discourse, Vol. 1. Norwood, NJ: Ablex.

McCarthy, L. M. (1987). A Stranger in Strange Lands: A College Student Writing across the Curriculum. Research in the Teaching of English (21), 233-65.

Miller, C. (1984). Genre as Social Action. Quarterly Journal of Speech (70), 151-67.

Myers, G. (2010). The Discourse of Blogs and Wikis. London: Continuum International Publishing Group.

Norwegian Directorate for Education and Training. (2012). Forsøk med adgang til å bruke Internett under eksamen. Retrieved from http://www.udir.no/Vurdering/Eksamen-videregaende/Forsok-Internett-under-eksamen/

Norwegian Ministry of Education's assessment guidelines for the 1999 EFL exam (The National Exam Committee 1999, preliminary edition).

Reform 94: The EFL subject curriculum, mandatory course in upper secondary school, 19942005. Norwegian Ministry of Education.

Rodgers, D., Sandor, C., \& Skifjeld, K. (2006). @cross. EFL Vg1 workbook. Oslo: N. W. Damm \& Søn.

Searle, J. R. (1969). Speech acts: an essay in the philosophy of language. Cambridge: Cambridge University Press.

Simensen, A. M. (1998). Teaching a Foreign Language. Principles and Procedures. Bergen: Fagbokforlaget.

Skulstad, A. S. (2002). Developing genre awareness in the "online era". In Simensen, A. M. (Ed.), Teaching and Learning Foreign Languages: Issues and Ideas (pp 141-160). Oslo: Unipub. 
Skulstad, A. S. (2009). The need for rethinking communicative competence. In Krumsvik, R. (Ed.), Learning in the Network Society and the Digitized School (pp. 255-267). New York: Nova Science Publishers, Inc.

Swales, J. (1990). Genre Analysis. Cambridge: Cambridge University Press.

Widdowson, H. G. (1998). Context, Community, and Authentic Language. TESOL Quarterly, 32 (4), 705-715. Retrieved from http://www.twu.ca/Library/tqd_2008/VOL_32_4.pdf

\section{Exam papers from the following years (The Norwegian Directorate for}

\section{Education and Training):}

Spring 1996; spring 1998; spring 1999; spring 2000; spring 2001; spring 2002; spring 2003; spring 2005.

Spring 2007; autumn 2007; spring 2008; spring 2009; spring 2010; autumn 2010, spring 2011; autumn 2011. 